\title{
$\mathrm{Cu} \mathrm{ECMP}$ 공정에서 전해액이 연마거동에 미치는 영향
}

\author{
권태영 · 김인권 · 김태곤 · 조병권* · 박진구 ${ }^{\dagger}$ \\ 한양대학교 금속재료공학과, *한양대학교 바이오나노공학과
}

\section{The Effect of Electrolytes on Polshing Behavior in $\mathrm{Cu}$ ECMP}

\author{
Tae-Young Kwon, In-Kwon Kim, Tae-Gon Kim, Byung-Gwun Cho* and Jin-Goo Park ${ }^{\dagger}$ \\ Department of Materials Engineering, Hanyang University, Sa-1-Dong, Gyeonggi-Do, Ansan, South Korea, 426-791 \\ *Department of Bio-nano Technology, Hanyang University, Sa-1-Dong, Gyeonggi-Do, Ansan, South Korea, 426-791
}

(2008년 4월 16일 접수 : 2008년 6월 17일 채택)

\begin{abstract}
The purpose of this study is to characterize various electrolytes on electrochemical mechanical planarization (ECMP). The ECMP system was modified from conventional CMP system to measure the potentiodynamic curve and removal rate of $\mathrm{Cu}$. The potentiodynamic curves were measured in static and dynamic states in investigated electrolytes using a potentiostat for the evaluation of the polishing behavior on ECMP. $\mathrm{KOH}$ (alkaline) and $\mathrm{NaNO}_{3}$ (salt) were selected as electrolytes which have high conductivity. In static and dynamic states, the corrosion potential decreased and the corrosion current increased as a function of the electrolyte concentration. But, the electrochemical reaction was prevented by mechanical polishing effect in the dynamic state. The static etch and removal rate were measured as functions of concentration and applied voltage. When $\mathrm{NaNO}_{3}$ was used, the dissolution was much faster than that of $\mathrm{KOH}$. It was concluded that the removal rate was strongly depended on electrochemical dissolution. The removal rate increased up to $350 \mathrm{~nm} / \mathrm{min}$ in $\mathrm{NaNO}_{3}$ based electrolyte.
\end{abstract}

Key words $\mathrm{Cu}$ ECMP, potentiodynamic curve, $\mathrm{KOH}, \mathrm{NaNO}_{3}$, electrochemical reaction.

\section{1. 서 론}

반도체 산업에서 다층구조의 금속 배선재료로써 높은 전도율(electrical conductivity)과 전기적 전자이동(electromigration)에 대한 저항성이 우수한 구리 $(\mathrm{Cu})$ 가 도입되어 사용되고 있으며, 완성도 높은 평탄도를 얻기 위해 다마 신(damascene) 기술을 사용한 CMP(chemical mechanical polanarization) 공정의 중요도가 높아지고 있다. 또한 반 도체소자의 고집적도에 따라 더욱 낮은 유전상수를 가지 는 저유전율(low-k) 재료가 필요하다. 하지만 구조적으로 기계적 스트레스에 취약한 저유전율 재료들은 기존의 $\mathrm{CMP}$ 공정에서의 높은 공정압력에 쉽게 손상을 받을 수 있다. 뿐만 아니라, CMP 슬러리(slurry)에 포함된 연마 입자에 의해 $\mathrm{Cu}$ 표면에 발생하는 스크레치(scractch), 디 싱(dishing)과 에로젼(erosion) 등의 결함을 발생시킨다.

이러한 $\mathrm{CMP}$ 공정의 기술적인 문제점들을 해결하기 위 해서, ECP(Electrocemical Polishing), ${ }^{1)}$ ECMP (Electrochemical Mechanical Polishing), ${ }^{2)}$ CE (Chemical Etching) ${ }^{3)}$

Corresponding author

E-Mail : jgpark@hanyang.ac.kr (J. -G.. Park)
등의 평탄화 방법들이 제시되어지고 있다. 특히, 최근에 많 은 연구와 주목받는 기술이 $\mathrm{ECMP}$ 이다. ECMP 공정은 전기화학적 반응과 기계적인 연마에 의해 구리 표면을 평 탄화를 가능하게 하는 공정이다. 특히, 구리의 전기화학적 용해(dissolution)과 부동태(passivation) 층을 형성시키는 전기화학적 반응이 $\mathrm{ECMP}$ 공정에서 가장 중요한 요소이 다. 그렇기 때문에, 전해액과 첨가제에 대한 연구가 중요 하다. ${ }^{4-6)}$ 그러나 $\mathrm{ECMP}$ 공정에서 중성 및 염기성 전해 액에 대한 연구는 많이 이루어지지 않고 있으며, 다양한 전해액에 따른 연마거동에 대한 이해가 이루어지지 않고 있는 실정이다. 본 연구에서는 중성과 염기성 전해액에 따른 ECMP 거동은 관찰하기 위해, ECMP 연마기를 제 작하였으며, potentiodynaic curve를 측정해 전기화학적 특성을 평가하였다.

\section{2. 실험 방법}

본 실험에서는 $1.5 \mu \mathrm{m}$ 의 두께로 도금된 구리 웨이퍼 (wafer)를 사용하였다. 전해질에 의한 식각율 및 전기화 학적 반응을 측정하기 위해서 $2.0 \times 2.0 \mathrm{~cm}^{2}$ 크기의 구리 웨이퍼를 사용하였으며, 연마율 측정을 위해 $99 \%$ 순도 
의 직경 $100 \mathrm{~mm}$ 구리 디스크(disc)를 사용하였다. 실험에 사용된 구리 웨이퍼의 표면은 유기물과 산화막(native oxide)을 제거하기 위해서 아세톤(aceton), IPA (isopropyl alcohol) 그리고 $\mathrm{HF}(\mathrm{DHF}, 0.5 \%)$ 에 각각 $1 \mathrm{~min}$ 동안 세정을 하였다.

ECMP 연마기는 poteniodynamic curve 측정 및 전기 화학반응에 의한 구리 연마율을 측정하기 위해서 제작되 었다. Fig. 1은 본 실험을 위해 개조된 연마기의 개략도 이다. 구리 디스크를 작업전극(working electrode, anode) 으로 사용하였으며, 연마 테이블에는 백금 $(\mathrm{Pt})$ 도금을 실 시하여 보조전극(counter electrode, cathode)으로 사용하 였으며, 기준전극(reference elecrode)으로는 SCE (saturated calomel electrode)를 사용하였다. 또한 연마패드 (Rohm and Haas Co., IC 1400)에는 $6 \mathrm{~mm}$ 의 일정한 크기의 구멍을 형성시켜서 전기화학반응이 원활하게 이 루어 질 수 있도록 하였다. Potentiodynamic curve는 flat cell을 이용한 정적(static) 상태에서와 연마기를 이용한 동적(dynamic) 상태에서 $1 \mathrm{mV} / \mathrm{sec}$ 의 속도로 측정을 하였 으며, 측정은 potentiostat (Princeton Applied Research $273 \mathrm{~A}$ )를 사용하여 EOC(open-circuit potential)을 기준으 로 $-0.25 \mathrm{~V}$ 에서 $1.5 \mathrm{~V}$ 까지 측정을 하였다.

실험에 사용된 전해질은 $\mathrm{KOH}$ 와 $\mathrm{NaNO}_{3}$ 이며, 농도변 화에 따른 potentiodynamic curve, 식각율, 전기화학적 식각율, 연마율의 측정을 통해 ECMP 거동을 살펴보았 다. 공정압력은 $1 \mathrm{psi}, \mathrm{CMP}$ 헤드와 테이블의 회전속도는 $30 \mathrm{rpm}$ 의 조건에서 실험을 실시하였다.

\section{3. 결과 및 고찰}

구리 웨이퍼 표면과 전해액과의 전기화학적 특성을 관 찰하기 위해서 $\mathrm{KOH}$ 와 $\mathrm{NaNO}_{3}$ 농도변화에 따른 정적인 상태에서의 potentiodynamic curve를 측정하였다.

Fig. 2는 $\mathrm{KOH}$ 의 농도변화에 따른 구리 표면의 potentiodynamic curve를 측정한 결과이다. $\mathrm{KOH}$ 의 농도가 $0.5 \mathrm{wt} . \%$ 에서 $5 \mathrm{wt} . \%$ 로 증가함에 따라 부식전위(corrosion potential)
는 $-0.236 \mathrm{~V}$ 에서 $-0.334 \mathrm{~V}$ 범위까지 미세하게 감소하였 으며, 농도가 증가할수록 구리표면과 전해액의 반응성이 증가한다는 것을 예상할 수 있었다. Eoc 대비 측정한 potentiodynamic curve에서는 $\mathrm{KOH}$ 의 모든 농도 범위에 서 전류밀도가 일정하게 유지되는 부동태 층이 생성되는 것이 관찰되었다. 하지만 $0.5 \mathrm{~V}$ 의 전위에서 potentiodynamic curve의 기울기가 증가현상이 관찰되었다. 이러 한 경향은 높아진 전위에 의해 부동태막이 손상을 입게

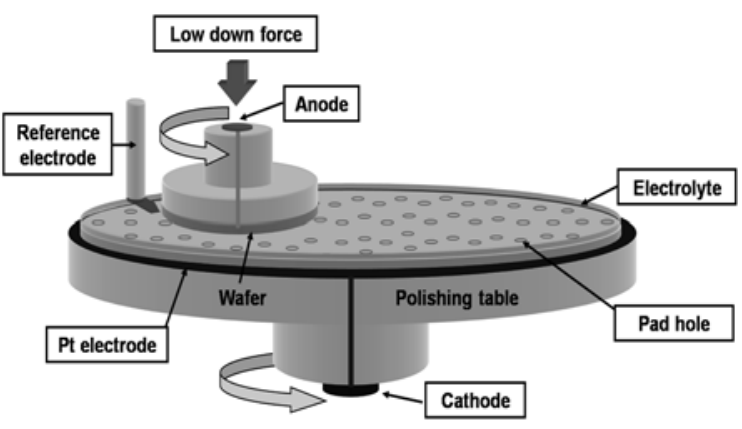

Fig. 1. Schematic diagram of ECMP system.

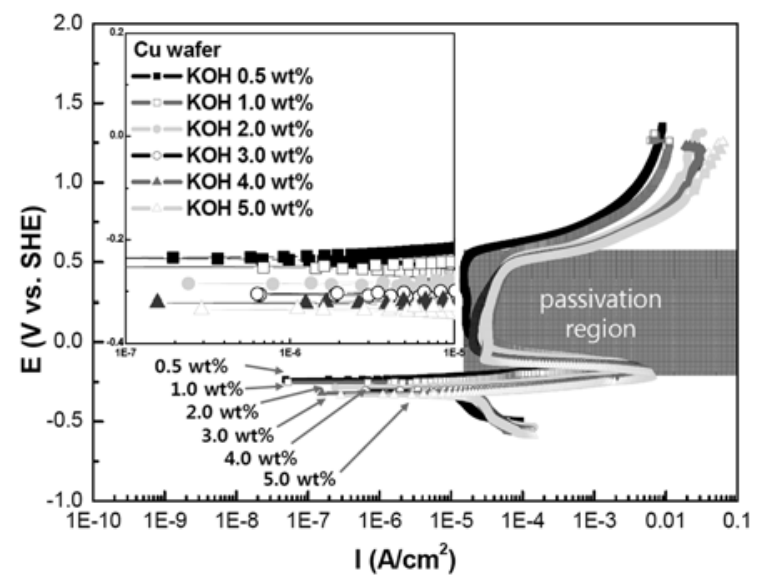

Fig. 2. Potentiodynamic curve of $\mathrm{Cu}$ surface in $\mathrm{KOH}$ electrolyte as a function of its concentration.

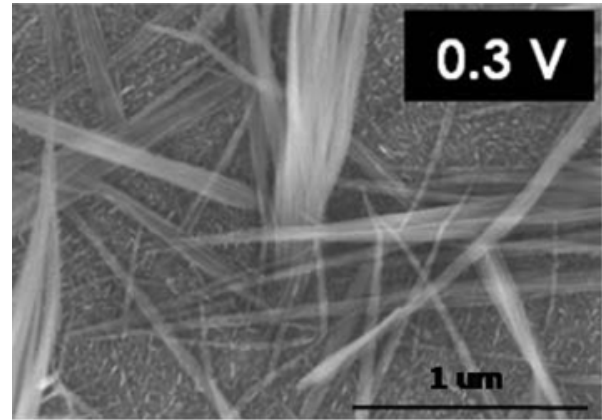

(a)

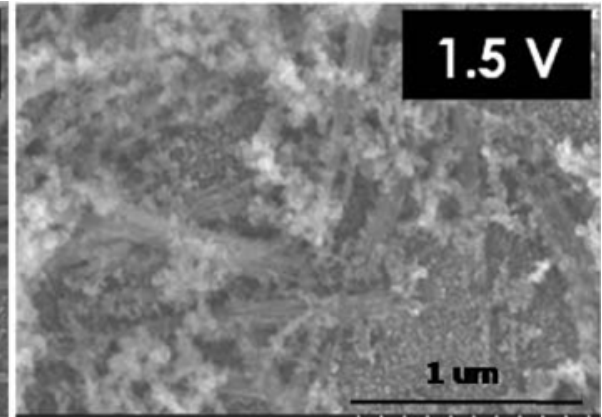

(b)

Fig. 3. SEM images of $\mathrm{Cu}$ surface in $\mathrm{KOH}(0.5$ wt.\%) electrolyte at applied potential of (a) $0.3 \mathrm{~V}$ and (b) $1.5 \mathrm{~V}$. 
되면서 다시 전류밀도가 증가하면서 나타나게 되고, 이 영역을 과부동태(Trans-pssivation) 영역이라고 한다. ${ }^{5)}$ Fig. 3 은 인가되는 전위에 따른 구리표면을 $\mathrm{SEM}$ 으로 측정한 결과이다. 구리의 경우 부동태 영역에서 표면에 $\mathrm{Cu}(\mathrm{OH})_{2}$ 가 형성되는 것으로 보고되고 있다. ${ }^{7)}$ Fig. 3(a)는 구리 표면에 부동태 막이 생성되었음을 보여준다. 형성된 부동 태층은 전위가 증가함에 따라 과부동태 영역에 도달하게

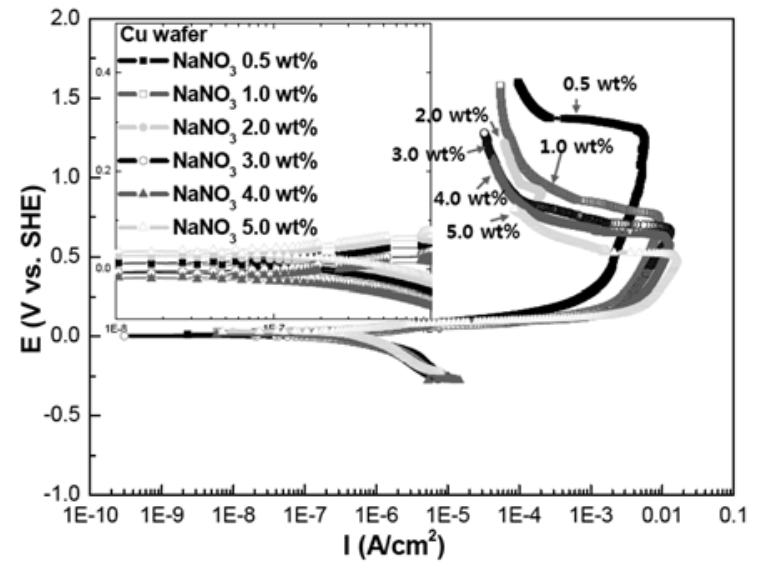

Fig. 4. Potentiodynamic curve of $\mathrm{Cu}$ surface in $\mathrm{NaNO}_{3}$ electrolyte as a function of its concentration.
되며 생성된 $\mathrm{Cu}(\mathrm{OH}) 2$ 는 높은 전위에 의해 Fig. 3(b)와 같이 손상을 입은 표면이 드러나기 시작한다.

Fig. 4는 $\mathrm{NaNO}_{3}$ 농도증가에 따른 구리 웨이퍼의 potentiodynamic curve를 보여준다. $\mathrm{KOH}$ 전해액과 비교하여 더 높은 전류밀도 영역에서 부동태 영역이 형성되었으며, 이 러한 현상은 $\mathrm{NaNO}_{3}$ 를 사용한 경우 용해반응이 부동태 층이 형성되는 반응보다 더 지배적으로 발생한다고 예상 할 수 있다. 또한 높은 전위영역에서 전류밀도가 급격히 감소하는 것을 확인할 수 있으며, 이는 $1.5 \mu \mathrm{m}$ 두께의 구리 박막이 모두 용해되어 실리콘 표면이 노출되어 구 리이온의 흐름이 없기 때문에 나타나는 현상이다. $\mathrm{NaNO}_{3}$ 농도가 증가할수록 더 낮은 전위에서 이러한 현상이 나 타났으며, 이것을 통해 전기화학적 용해능력이 농도 증가 에 비례하는 것을 확인 할 수 있었다.

Fig. 5는 $0.3 \mathrm{~V}$ 와 $1.5 \mathrm{~V}$ 에서 $0.5 \mathrm{wt} . \%$ 농도의 $\mathrm{NaNO}_{3}$ 와 구리 표면의 전기화학반응에 의한 용해현상을 관찰한 결 과이다. $0.3 \mathrm{~V}$ 에서 전기화학적 반응에 의해 구리 표면이 용해되기 시작하였으며, $1.5 \mathrm{~V}$ 의 높은 전위에서는 $1.5 \mu \mathrm{m}$ 두께의 구리 박막이 모두 용해되어 기판인 실리콘이 드 러남을 확인할 수 있었다. 중성 전해질인 $\mathrm{NaNO}_{3}$ 를 사용 할 경우, 전기화학적 용해능력은 농도와 전위에 비례하는 것을 확인할 수 있었다.

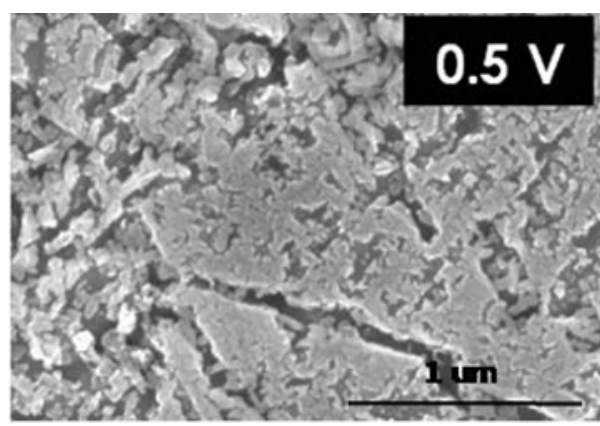

(a)

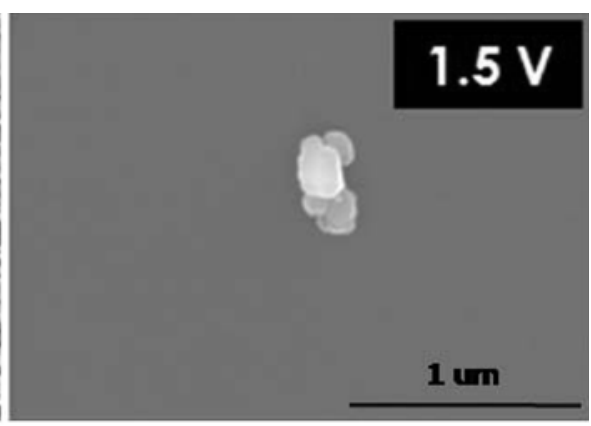

(b)

Fig. 5. SEM images of $\mathrm{Cu}$ surface in $\mathrm{NaNO}_{3}(0.5$ wt.\%) electrolyte at applied potential of (a) $0.3 \mathrm{~V}$ and (b) $1.5 \mathrm{~V}$.

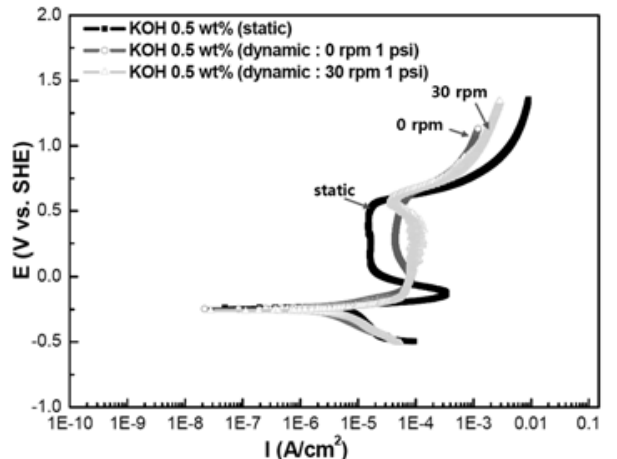

(a)

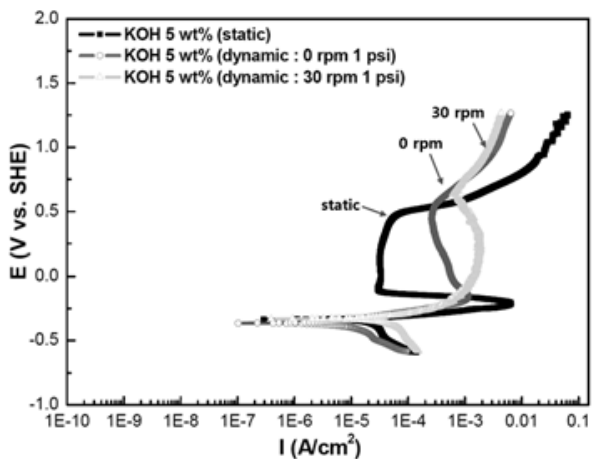

(b)

Fig. 6. Potentiodynamic curves of $\mathrm{Cu}$ in $\mathrm{KOH}$ electrolyte at static state and table rotation speed of $0 \mathrm{rpm}$ and $30 \mathrm{rpm}$; $\mathrm{KOH}$ (a) 0.5 wt. $\%$, (b) 5 wt.\%. 


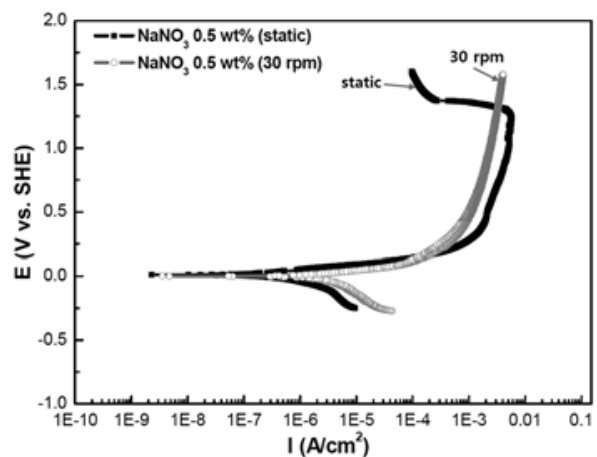

(a)

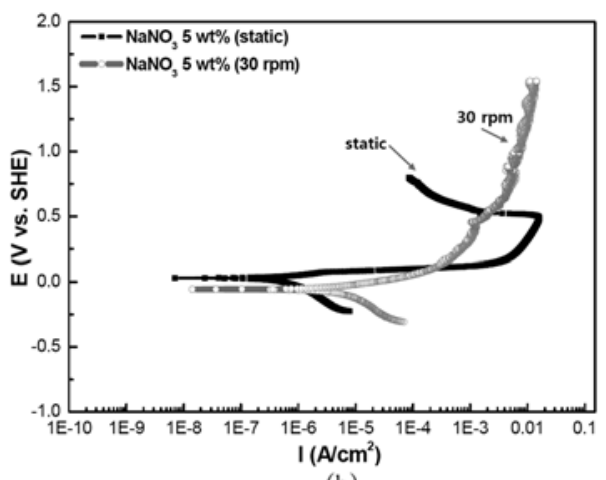

(b)

Fig. 7. Potentiodynamic curves of $\mathrm{Cu}$ in $\mathrm{NaNO}_{3}$ electrolyte at static state and table rotation speed of $30 \mathrm{rpm} ; \mathrm{NaNO}_{3}$ (a) 0.5 wt.\%, (b) 5 wt.\%.

실제 공정 중에 발생하는 전기화학적 연마거동을 관찰 하기 위해서 개조된 ECMP 연마기를 이용하여 공정압력 과 $\mathrm{CMP}$ 헤드 및 테이블의 회전속도가 연마거동에 미 치는 영향을 확인하였다.

Fig. 6은 plat cell을 사용한 경우와 전기화학적 연마기를 사용하여 공정압력 $(1 \mathrm{psi})$ 과 회전 $(0 \mathrm{rpm}, 30 \mathrm{rpm})$ 을 가해 준 경우의 potentiodynamic curve를 보여주고 있다. Fig. $6(\mathrm{a})$ 와 $(\mathrm{b})$ 는 각각 $\mathrm{KOH} 0.5 \mathrm{wt} . \%$ 와 $5 \mathrm{wt} . \%$ 에서의 결과 를 보여준다. $\mathrm{KOH} 0.5 \mathrm{wt} . \%$ 의 전해액을 Plat cell을 사 용하였을 경우 부동태 층은 $1.6 \times 10^{-5} \mathrm{~A} / \mathrm{cm}^{2}$ 영역에서 유 지되었으나, 실제 연마조건에서는 부동태가 영역의 전류밀 도가 증가하였다. 또한 산화반응 이후 부동태 층의 형 성으로 인한 전류밀도의 감소폭은 회전력이 증가함에 따 라 Fig. 6(a)와 같이 줄어들었으며, 이는 안정적인 부동 태층의 형성이 제한되는 것으로 판단된다. Fig. 6(b)에서의 $5 \mathrm{wt} . \%$ 전해액에서도 이와 같은 현상을 관찰할 수 있었다.

Fig. 7은 중성 전해질 $\mathrm{NaNO}_{3}$ 농도변화에 따른 plat cell을 사용한 경우와 전기화학적 연마기를 사용하여 공 정압력 $(1 \mathrm{psi})$ 과 회전(30 rpm)을 가해준 경우의 potentiodynamic curve를 보여주고 있다. Fig. 7(a)은 $\mathrm{NaNO}_{3}$ $0.5 \mathrm{wt} \%$ 의 농도에서의 연마상태가 전기화학적 반응에 미 치는 영향을 보여준다. $0.5 \mathrm{~V}$ 에서의 전류밀도를 비교하였 을 경우, $2.11 \times 10^{-3} \mathrm{~A} / \mathrm{cm}^{2}$ 에서 $0.95 \times 10^{-3} \mathrm{~A} / \mathrm{cm}^{2}$ 으로 감 소하였다. Fig. 7(b)는 $\mathrm{NaNO}_{3} 5 \mathrm{wt} . \%$ 의 경우를 나타내 며, $0.5 \mathrm{~V}$ 에서 비교하였을 경우, 전류밀도는 $22.4 \times 10^{-3}$ $\mathrm{A} / \mathrm{cm}^{2}$ 에서 $1.11 \times 10^{-3} \mathrm{~A} / \mathrm{cm}^{2}$ 으로 감소하였다. 전기화학적 용해반응이 지배적인 $\mathrm{NaNO}_{3}$ 전해액에서는 실제 공정조 건에서 용해 반응이 감소한 전류밀도 영역에서 부동태가 나타나는 것을 확인하였다. 이것은 공정압력과 회전과 같 은 실제 공정 요소들이 전기화학적 반응을 방해 또는 감 소시키는 것이라 생각되어진다.

Fig. 8(a) 와 (b)는 $\mathrm{KOH}$ 와 $\mathrm{NaNO}_{3}$ 전해질에서 전기화 학적 식각율을 측정한 결과를 보여준다. 전기적 용해반 응이 활발하게 발생하는 $\mathrm{NaNO}_{3}$ 는 농도 증가와 인가된

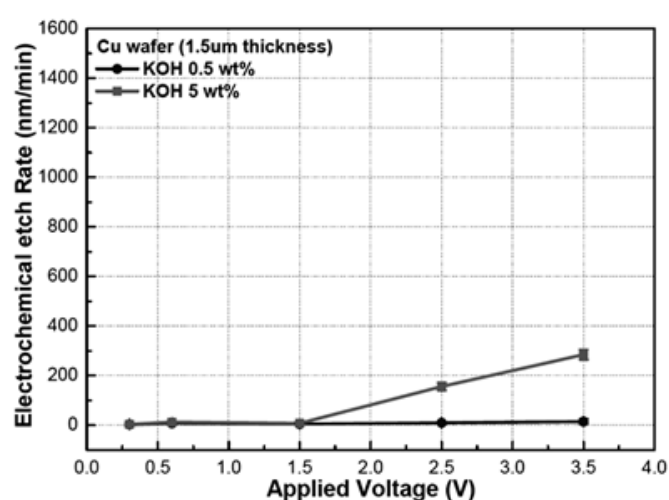

(a)

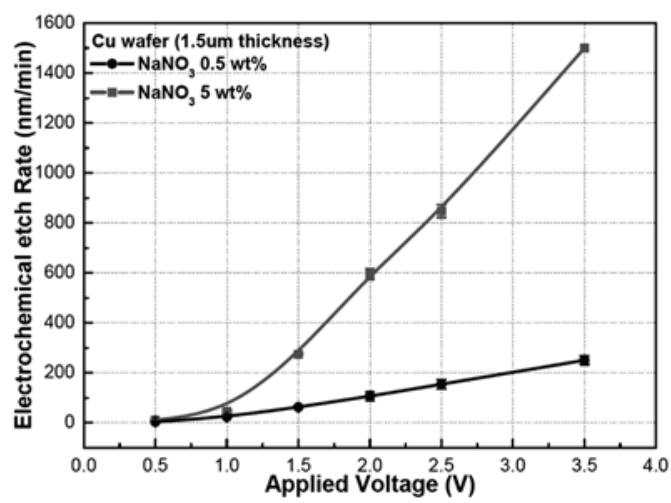

(b)

Fig. 8. Electrochemical etch rates of $\mathrm{Cu}$ in (a) $\mathrm{KOH}$ and (b) $\mathrm{NaNO}_{3}$ electrolytes as a function of applied potential.

전압이 증가 될수록 전기화학적 식각율이 증가 하였으며, $5 \mathrm{wt} . \%$ 농도에서 $3.5 \mathrm{~V}$ 의 전압이 인가되었을때, $1.5 \mu \mathrm{m} /$ $\min$ 이상이 전기화학적 반응에 의해 식각되었다. $\mathrm{KOH}$ 를 사용하였을 경우 부동태 반응이 지배적이기 때문에 전 기화학적 식각율이 $5 \mathrm{wt} . \%$ 농도에서 $3.5 \mathrm{~V}$ 의 인가된 전 압에서도 $200 \mathrm{~nm} / \mathrm{min}$ 정도의 식각율이 나타났다.

Fig. 9(a)와 (b)는 $\mathrm{KOH}$ 와 $\mathrm{NaNO}_{3}$ 전해질을 사용하여 $\mathrm{ECMP}$ 공정을 실행하였을 때 구리의 연마율을 보여준다. 


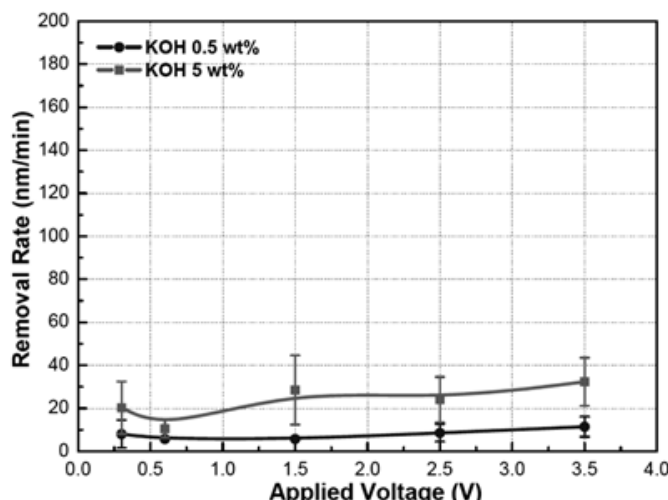

(a)

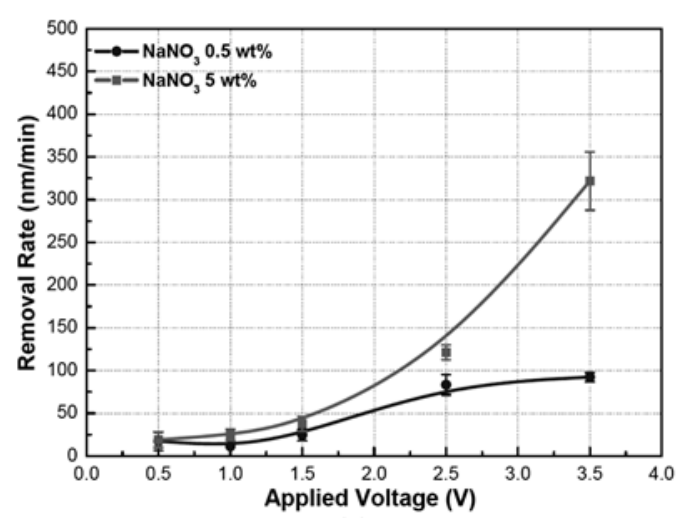

(b)

Fig. 9. Removal rate of $\mathrm{Cu}$ in (a) $\mathrm{KOH}$ and (b) $\mathrm{NaNO}_{3}$ as a function of applied potential.

$\mathrm{KOH}$ 는 $5 \mathrm{wt} . \%$ 농도에서도 모든 전위영역에 걸쳐서 $30 \mathrm{~nm} /$ $\min$ 이하의 연마율이 측정되었다. 하지만 상대적으로 전 기화학적 용해반응이 지배적인 $\mathrm{NaNO}_{3}$ 의 경우, 기계적인 요소에 의해 전기화학반응은 감소하였지만, $5 \mathrm{wt} . \%$ 의 농도 에서 $3.5 \mathrm{~V}$ 의 전압이 인가되었을 때, 최대 $350 \mathrm{~nm} / \mathrm{min}$ 얻을 수 있었다.

\section{4. 결 론}

본 연구에서는 차세대 CMP 기술로 보고되어지고 있는 ECMP 공정에서 전해질과 구리 웨이퍼의 전기화학적 반응 과 기계적 요소가 연마 거동에 미치는 영향에 대해 살 펴보았다.

전해질과 구리 웨이퍼 표면과의 전기화학적 반응에 대한 거동은 potentiodynamic curve를 통해 관찰하였다. 기계적 요소가 포함된 동적인 상태의 potentiodynamic curve 측정 을 위해 $\mathrm{ECMP}$ 용 연마기를 제작하여 사용하였다. 정적 상태의 potentiodynamic curve를 통해 중성 전해액인
$\mathrm{NaNO}_{3}$ 를 사용하였을때, 염기성 전해액인 $\mathrm{KOH}$ 보다 전기 화학적 용해반응이 지배적으로 나타남을 알 수 있었고, $\mathrm{KOH}$ 는 상대적으로 부동태 반응이 지배적으로 나타남을 알 수 있었다. 또한 전기화학적 반응은 전해액 농도증가 와 비례한 반응성을 보였다. 동적상태의 potentiodynamic curve 측정을 통해, 연마헤드와 연마테이블의 회전거동과 같은 기계적 요소에 의해 부동태 반응 및 전기화학적 용 해 반응성이 감소하는 것을 확인 할 수 있었다. 사용된 전해액을 $\mathrm{ECMP}$ 공정에 적용하기 위해서 전기화학적 식 각율과 연마율을 측정하였으며, 기계적 요소에 의해 전 기화학 반응의 감소로 인해 해서 연마율이 식각율보다 낮 게 측정되었다. 전기화학적 연마율 측정을 통해서도 같은 결과가 도출되었다. 이는 potentiodynamic curve 결과에 서와 같이 연마시편인 구리와 보조전극으로 이용되는 연 마 테이블이 연속적인 회전과, 부도체인 연마패드에 의해 전기화학 작용이 제한되는 것으로 예상된다. 최종적으로 전기화학적 용해반응이 활발한 $5 \mathrm{wt} . \% \mathrm{NaNO}_{3}$ 를 사용하 여, $3.5 \mathrm{~V}$ 에서 $350 \mathrm{~nm} / \mathrm{min}$ 의 연마율을 얻었다.

\section{감사의 글}

본 과제는 교육인적자원부, 산업자원부, 노동부의 출연금 및 보조금으로 수행한 최우수실험실지원사업과 한국과학 재단에서 시행된 특정기초연구지원사업에 의해 실시된 연 구결과 입니다.

\section{참 고 문 헌}

1. S. C. Chang, J. M. Shieh, C. C. Huang, B. T. Dai, and M. S. Feng, Jpn. J. Appl. Phys., 41, 7332 (2002).

2. L. Economikos, X. Wang, X. Sakamoto, P. Ong, M. Naujok, R. Knarr, L. Chen, Y. Moon, S. Neo, J. Salfelder, A. Duboust, A. Manens, W. Lu, S. Shrauti, F. Liu, S. Tsai, and W. Swart, Proceedings of the IEEE 2004 International Interconnect Technology Conference, p.233 (2004).

3. J. Pallinti, S. Lakshminarayanan, W. Barth, P. Wright, M. Lu, S Reder, L. Kwak, W. Catabay, D. Wang, and F. Ho, Proceedings of the IEEE 2003 International Interconnect Technology Conference, p.83 (2003).

4. P. C. Goonetilleke, and D. Roy, Materials Chemistry and Physics, 94(2), 388 (2005).

5. S. J. Lee, Y. M. Lee, and M. F. Du, J. Master. Process. Tech., 140(1), 280 (2003).

6. Y. J. Oh, G. S. Park, and C. H. Chung, J. Electrochem. Soc., 153(7), G617 (2006).

7. J. G. Becerra, R. C. Salvarezza, and A. J. Arvia, Electrochimica Acta, 33(5), 613 (1988). 